\title{
Giant cell tumor of the frontal sinus: case report*
}

Tumor de células gigantes do seio frontal: relato de caso

\author{
João Paulo Matushita ${ }^{1}$, Julieta S. Matushita ${ }^{2}$, Luiz Antonio Monteiro Simões ${ }^{3}$, Lizando Franco \\ de Carvalho $\mathrm{Neto}^{4}$, Cristina S. Matushita ${ }^{5}$, João Paulo Kawaoka Matushita Junior ${ }^{6}$
}

\begin{abstract}
The authors report the case of a giant cell tumor of the frontal sinus in a 54-year-old male patient. This tumor location is rare, and this is the third case reported in the literature with radiographic documentation and histopathological confirmation. The patient underwent surgery, with curettage of frontal sinus and placement of a prosthesis. He died because a voluntary abrupt discontinuation of corticosteroids.
\end{abstract}

Keywords: Giant cell tumors; Paranasal sinus; Radiology; Diagnosis.

Resumo Apresentamos um caso de tumor de células gigantes do seio frontal, num paciente do sexo masculino de 54 anos de idade. É tumor de localização rara, sendo o terceiro caso relatado na literatura mundial, com documentação radiográfica e confirmação histopatológica. O paciente foi submetido a intervenção cirúrgica, com curetagem dos seios frontais e colocação de uma prótese, falecendo por supressão abrupta voluntária de corticosteroides.

Unitermos: Tumor de células gigantes; Seios paranasais; Radiologia; Diagnóstico.

Matushita JP, Matushita JS, Simões LAM, Carvalho Neto LF, Matushita CS, Matushita Junior JPK. Giant cell tumor of the frontal sinus: case report. Radiol Bras. 2013 Jul/Ago;46(4):255-258.

\section{INTRODUCTION}

Giant cell tumors are not so commonly found as they were supposed to be - their mean incidence corresponds to $3.9 \%$ of all bone tumors ${ }^{(\mathbf{1})}-$, and are preferentially located in long bones (femur and tibia), sacrum, vertebrae ${ }^{(2)}$ and patella ${ }^{(3)}$, most of times affecting young adult individuals, with eccentric metaphyseal location and immediately after the epiphyseal closure.

Occurrence of such tumors in the cephalic segment is rarely observed, and most

* Study developed at the Service of Radiology, Santa Casa de Misericórdia do Rio de Janeiro and at the Service of Radiology, Hospital dos Servidores do Estado/INAMPS, Rio de Janeiro, RJ, Brazil.

1. PhD, Medical Coordinator and Head of UFADTI, Hospital das Clínicas da Universidade Federal de Minas Gerais (UFMG) Belo Horizonte, MG, Brazil.

2. MD, Radiologist, Centro de Diagnóstico por Imagem Dr. Matsushita, Belo Horizonte, MG, Brazil.

3. MD, Neurosurgery, ex-Resident, Hospital dos Servidores do Estado/INAMPS, Rio de Janeiro, RJ, Brazil.

4. MD, Anatomopathologist, ex-Resident, Hospital dos Servidores do Estado/INAMPS, Rio de Janeiro, RJ, Brazil.

5. Nuclear Physician, Hospital Universitário Clementino Fraga Filho - Universidade Federal do Rio de Janeiro (UFRJ), Rio de Janeiro, RJ, Brazil.

6. Fellow Master degree, School of Medicine, Universidade Federal do Rio de Janeiro (UFRJ), Rio de Janeiro, RJ, MD, Radiologist, Centro de Diagnóstico por Imagem Dr. Matsushita, Belo Horizonte, MG, Brazil.

MailingAddress: Dr. João Paulo Matushita. Rua Caetés, 530/ 216, Centro. Belo Horizonte, MG, Brazil, 30120-080. Email. jpauloejulieta@gmail.com.

Received March 5, 2012. Accepted after revision January 2, 2013 frequently they are located in the mandible, maxilla, temporal bone and calvarium. However, cases of involvement of other craniofacial bone elements are extremely rare, like in zygomatic bone ${ }^{(4)}$, external auditory meatus ${ }^{(5)}$, petrosal pyramid ${ }^{(6)}$, frontal bone ${ }^{(7)}$, occipital bone ${ }^{(8)}$, ethmoid bone $^{(\mathbf{9})}$, sphenoid bone ${ }^{(\mathbf{3 , 6 , 1 0 - 1 2})}$, sphenoidal sinus $^{(\mathbf{1 3})}$, mandibular condyle ${ }^{(\mathbf{1 4})}$ and jugular foramen ${ }^{(15)}$.

The present article describes a case of a patient with giant cell tumor in the frontal sinus, with radiographic and histopathological documentation and report on the clinical evolution of the disease. In the global literature review, the authors have found only two cases of giant cell tumor in the frontal sinus described in 1974 by Hlavácek et al. ${ }^{(\mathbf{1})}$.

\section{CASE REPORT}

A 54-year-old, married tradesman with leukoderma, born in Trás-os-Montes (Portugal), and living in Santa Cruz, RJ for 27 years.

Two months ago, the patient presented an insidious onset of a subtle edema in his intersuperciliary region that was painless at palpation, warm, non throbbing and without any type of secretion. Local hyperemia was observed. The tumor-like lesion pre- sented progressive growth. The patient reported onset of preorbital edema, initially more intense at right and later, at left, with pain at compression of the upper palpebral region bilaterally and at the superciliary region.

General clinical examination revealed the presence of a tumor at the level of the frontal bone, affecting principally the left eye. Supplementary tests results were the following: syphilis serodiagnosis; quantitative complement fixation test - 18:0; Kahn test - reactive; microflocculation reaction - VDRL - reactive; blood count normal; urinalysis - normal; biochemical blood test - normal.

Antibiotic therapy was instituted, but no satisfactory outcome was observed. On May 30, 1978 the patient underwent radiography of facial sinuses (fronto- and mentonasal views) and of the skull (anteroposterior and lateral views) whose images demonstrated osteolytic lesions in the frontal sinuses, destructing the wall of the upper medial lamina towards the left orbit and extending towards the posterior wall and subcutaneous tissue (Figure 1). The radiological findings suggested the presence of a malignant, primitive lesion.

The hypothesis of osteomyelitis was considered as differential diagnosis. On June 15,1978 , the patient underwent cra- 

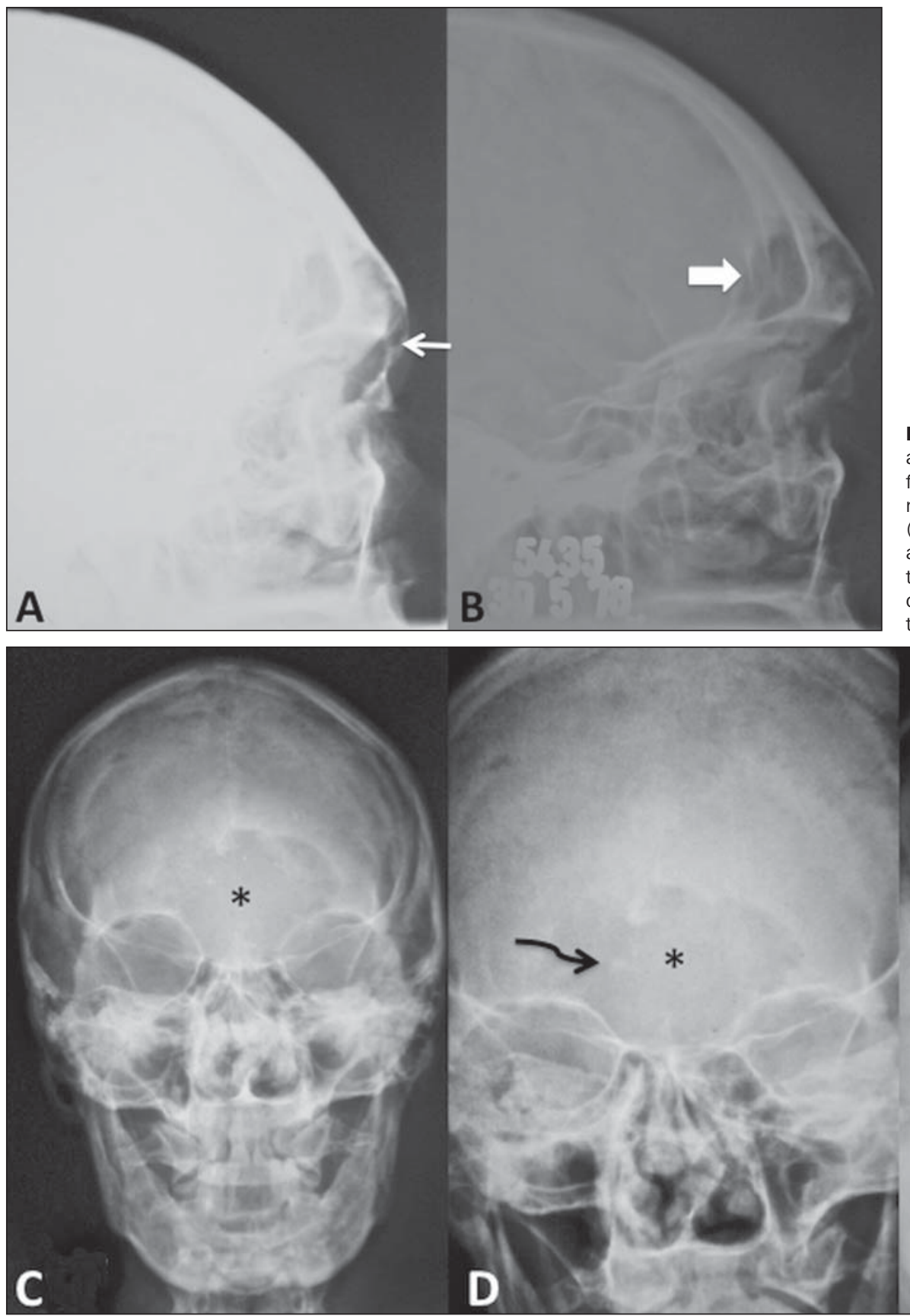

nial-facial computed tomography. Pre- and post-contrast tomographic sections of both orbitae and of the skull demonstrated the presence of a tumor in the left frontal region extending towards to the corresponding ethmoid sinus and destructing the upper medial lamina of the ipsilateral orbit. Such a frontal sinus mass caused bone destruction of its anterior border, invading the subcutaneous tissue, the posterior wall of the frontal sinus and the upper medial wall of the orbit. take by the tumor, except in the region of the frontal lobes. The left ocular globe was anterolaterally deviated (Figure 2). The ventricular cavities were normal, with absence of midline structures deviation.

The patient underwent surgery, with frontal sinuses curettage and placement of prosthesis. Histopathological analysis demonstrated mononuclear inflammatory infiltrate with plentiful giant multinucleated cells and ovoid or spindle cells in the vas-
There was not significant contrast up-
Figure 1. Lateral skull radiograph for soft parts $(\mathbf{A})$ and for bone parts $(\mathbf{B})$, posteroanterior view $(\mathbf{C})$ and facial sinuses on frontonasal view (D) and mentonasal view (E). Osteolytic lesions of frontal sinuses (asterisk) with intermingled bone fragments (curved arrow) destructing the wall of the upper medial lamina towards the left orbit (arrowheads), its border anteriorly to the subcutaneous tissue (thin arrow) and extending towards it posterior wall (bold arrow).

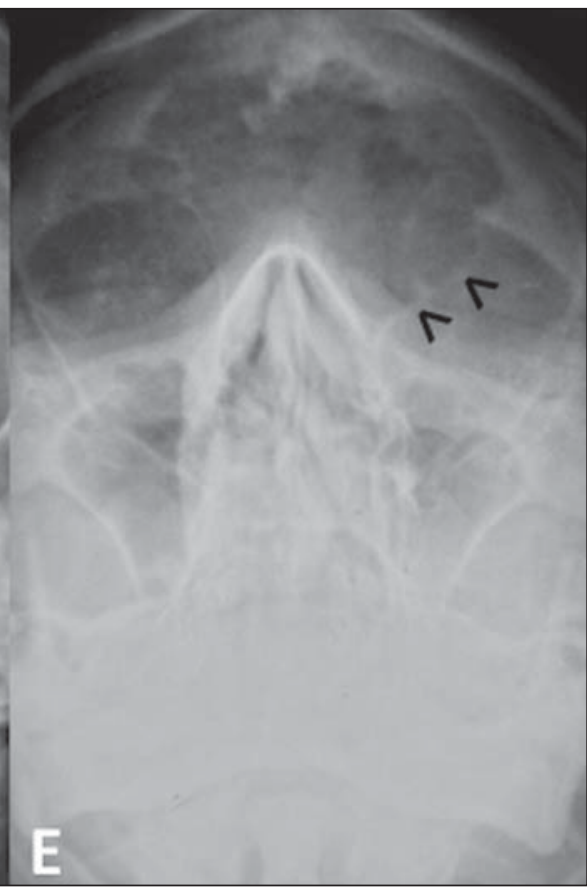

cular stroma. The findings were histologically confirmed as a giant cell tumor of frontal sinuses (Figure 3).

After the surgery, the patient was submitted to radiotherapy and corticosteroid therapy, but ended up dying because of voluntary abrupt discontinuation of corticosteroids.

\section{DISCUSSION}

Malignant head and neck tumors represent approximately $3 \%$ of neoplasms in 


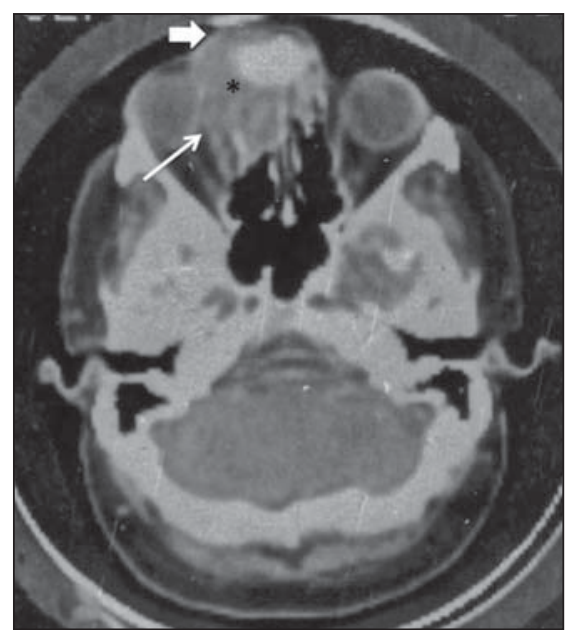

Figure 2. Contrast-enhanced skull computed tomography showing the presence of a tumor in the left frontal region (asterisk) extending towards the corresponding ethmoid air cells, destructing its medial wall (papyraceous lamina) of the ipsilateral orbit (thin arrow). Such frontal sinus tumor causes bone destruction in its anterior border, invading the subcutaneous tissue (bold arrow), the posterior wall of the frontal sinus and the upper medial wall of the orbit. Significant uptake was not observed after contrast injection, except in the frontal lobes region. Anterior and lateral deviation of the left ocular globe is observed.

general $^{(\mathbf{1 3 - 1 5 )}}$. Many of such tumors are squamous cell carcinomas, and the others include principally adenocarcinomas, adenoid cystic carcinomas, melanomas and lymphomas. Other malignant primary tumors of paranasal cavities are extremely $\operatorname{rare}^{(13-15)}$.

Giant cell tumors histiogenesis is dubious, however, for many, such tumors originate from non osteogenic connective tissue preferentially with eccentric, metaphyseal location in long bones of young adult individuals after the epiphyseal closure, with- out affecting the joints. Male and female individuals are equally affected in the cephalic segments.

Because of the low frequency of giant cell tumors in the cephalic segments (skull and face), Lichtenstein, in $1965^{(\mathbf{1 6})}$, affirmed that, before accepting a diagnosis of giant cell tumor in such sites, a careful histological investigation is required.

As criteria to establish the malignancy degree, one should consider the number of giant cells and respective nuclei, the mitotic index, osteoid development, and the presence of cell atypias or metaplasias ${ }^{(\mathbf{1 7})}$.

Giant cell tumors were formerly considered benign, but in the last years, the clinical experience has demonstrated that such tumors are aggressive and present malignancy potential in about $20 \%$ of cases. Because of the high frequency of local recurrence, total tumor resection has been recommended with replacement by endoprosthesis (Figure 4). Unfortunately, at the moment of the diagnosis, many of such neoplasias are found at advanced stages of disease, with prevalence of local invasion.

In the cases reported by Hlavácek et al. and by ourselves, frontal sinuses opacity with soft tissue density were found at radiography, in association with bone destruction and adjacent structures invasion, which actually correspond to characteristics of neoplastic lesions of paranasal sinuses. The screening for diseases of such cavities should be started with conventional paranasal sinuses radiography. Computed tomography is the best imaging method to evaluate bone destruction and disease extension towards adjacent struc-

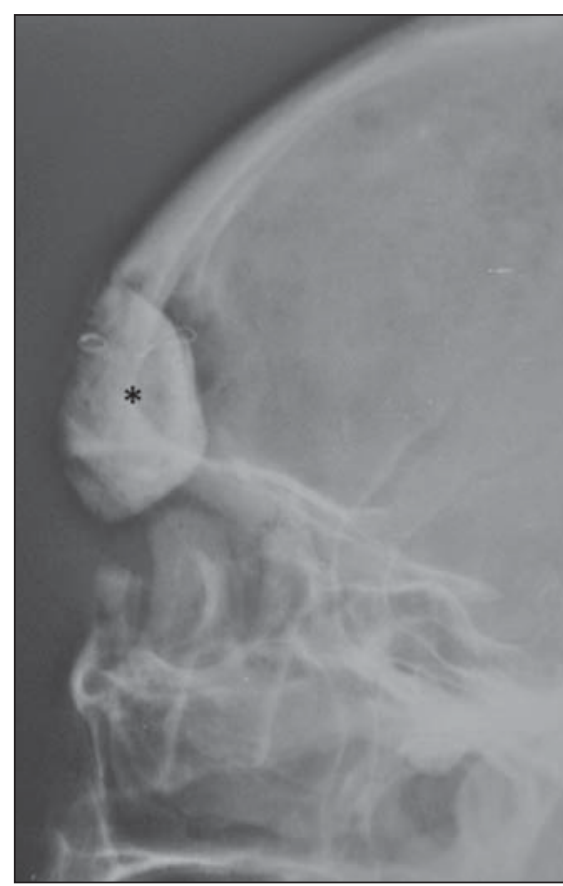

Figura 4. Pós-operatório com prótese (asterisco) de seio frontal.

tures. Currently, magnetic resonance imaging is the method of choice to detect soft tissue invasion by the tumor and to differentiate between retained secretion and tumor. The definitive diagnosis is made by histopathological investigation.

\section{REFERENCES}

1. Hlavácek V, Jolma VH. Giant cell tumors of bone in the E.N.T. organs. Report of two cases in the frontal sinus. Acta Otolaryngol. 1974;77:374-80.

2. Kos CB, Taconis WK, Fidler MW, et al. Multifocal giant cell tumors in the spine. A case report. Spine (Phila Pa 1976). 1997;22:821-2.

3. Gee VR, Pugh DG. Giant-cell tumor of bone. Radiology. 1958;70:33-45.

4. Hafeez MA, Tandon PL, Singhai SL, et al. Giant
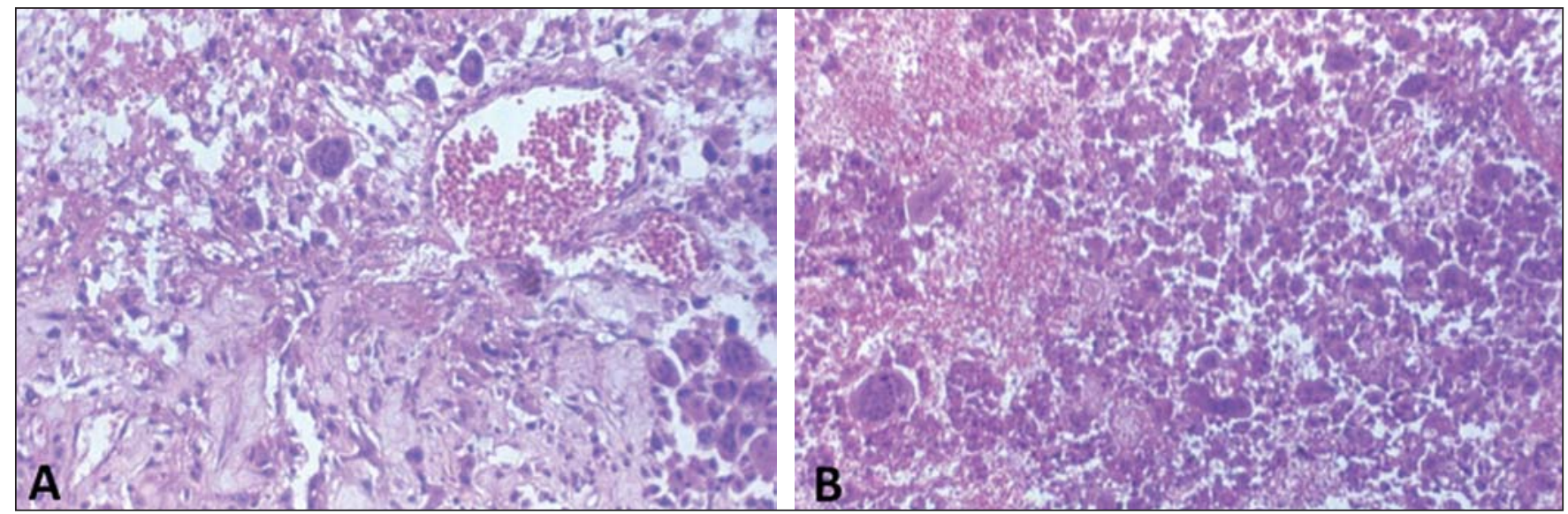

Figure 3. Histopathological slides. Mononuclear inflammatory infiltrate with numerous multinuclear cells is observed. 
cell tumor of the zygomatic bone. J Indian Med Assoc. 1964;42:126-7.

5. Shrivastava JB, Sharma KD. Osteoclastoma from the temporal bone. Indian J Surg. 1954;16:100-1.

6. Lee MY, Lee EJ. Giant cell tumor of the petrous temporal bone with direct invasion into the middle ear. J Craniofac Surg. 2006;17:794-800.

7. Felsberg GJ, Tien RD, McLendon RE. Frontoethmoidal giant cell reparative granuloma. AJNR Am J Neuroradiol. 1995;16:1551-4.

8. Giffin ME, Love JG. Giant cell tumor of the occipital bone with increased intracranial pressure. Report of case. Proc Staff Meet Mayo Clin. 1945; 20:284-7.

9. McKinney AM, Reichert P, Short J, et al. Meta- chronous, multicentric giant cell tumor of the sphenoid bone with histologic, CT, MR imaging, and positron emission tomography/CT correlation. AJNR Am J Neuroradiol. 2006;27:2199-201.

10. Chan J, Gannon FH, Thompson LD. Malignant giant cell tumor of the sphenoid. Ann Diagn Pathol. 2003;7:100-5.

11. Della Sala SW, Recla M, Campolongo F, et al Giant cell tumour of the mandibular condyle. Eur Radiol. 1996;6:557-60.

12. Rosenbloom JS, Storper IS, Aviv JE, et al. Giant cell tumors of the jugular foramen. Am J Otolaryngol. 1999;20:176-9.

13. Mendonça VF, Carvalho ACP, Freitas E, et al. Tumores malignos da cavidade nasal: avaliação por tomografia computadorizada. Radiol Bras. 2005;38:175-80.

14. Dulguerov P, Jacobsen MS, Allal AS, et al. Nasal and paranasal sinus carcinoma: are we making progress? A serie of 220 patients and systematic review. Cancer. 2001;92:3012-29.

15. Katz TS, Mendenhall WM, Morris CG, et al. Malignant tumors of the nasal cavity and paranasal sinuses. Head Neck. 2002;24:821-9.

16. Lichtenstein L. Bone tumours. 3rd ed. St Louis, MO: CV Mosby; 1965.

17. Jaffe JL, Lichtenstein L, Portis RB. Giant cell tumor of bone: its pathologic appearance, grading, and supposed variants and treatment. Arch. Pathol. 1940;30:993-1031. 